\title{
Separation of transglutaminase by thermo-responsive affinity precipitation using L-thyroxin as ligand
}

\author{
Sipeng Li, Zhaoyang Ding and Xuejun Cao*
}

*Correspondence: caoxj@ecust.edu.cn State Key Laboratory of Bioreactor

Engineering, Department of Bioengineering, East China University of Science and Technology, Shanghai 200237, China

\begin{abstract}
Transglutaminase (TGase) is widely used in the food industry. In this study, TGase was purified by affinity precipitation using L-thyroxin, coupled to a thermo-responsive polymer $\left(P_{N B N}\right)$, as an affinity ligand. The lower critical solution temperature and recovery of the affinity polymer were $31.0^{\circ} \mathrm{C}$ and $99.6 \%$, respectively. The optimal adsorption condition was $0.02 \mathrm{~mol} / \mathrm{L}$ phosphate buffer ( $\mathrm{pH}$ 5.0). The recoveries $99.01 \%$ (protein) and $98.85 \%$ (activity) were obtained by $0.2 \mathrm{~mol} / \mathrm{L}$ Gly-NaOH buffer ( $\mathrm{pH} 10.0$ ) as the elution agent. Circular dichroism spectroscopy and FortéBio Octet system were used to explore the interactions between L-thyroxin and TGase. The results show that L-thyroxin is suitable for affinity precipitation of TGase. The purity of the final product was verified using sodium dodecyl sulfate polyacrylamide gel electrophoresis.
\end{abstract}

Keywords: Affinity precipitation, Transglutaminase, Thermo-responsive polymer, L-Thyroxin

\section{Background}

Transglutaminase (TGase; EC 2.3.2.13) is an enzyme that can catalyze the acyl-transfer reaction from the $\gamma$-carboxamide group of a glutamine residue to the $\varepsilon$-amino group of a lysine residue (Grossowicz et al. 1950; Folk 1980). The cysteine at the active site of TGase can generate covalent cross-links with the glutamyl residue, which acts as an acyl donor, resulting in $\varepsilon$-( $\gamma$-Glu)-Lys bonds among proteins or peptides (Chica et al. 2004). When water molecules act as the acyl receptor, the deamidation of the glutamine and formation of a glutamine acid occur (Pardin et al. 2009). This enzyme therefore has a wide range of applications in food, drugs, immune studies, and metabolism (Binsi and Shamasundar 2012).

The forms and sources of TGase are diverse, and it can be obtained from plants, mammals, microorganisms, fish, and some marine organisms. Based on the origin and properties of the enzyme, TGases can be divided into tissue TGase and microbial TGase (Wilhelm et al. 1996; Worratao and Yongsawatdigul 2005). TGase from microorganism has been widely used in the food industry since the early 1980s (Zhao et al. 2010). Proteins play an important role in the nutritional values and composition of most foods, and TGase can cross-link many important food proteins such as casein and soy proteins. These modifications by TGase affect the solubility, gelation, emulsification, and other

(c) $2016 \mathrm{Li}$ et al. This article is distributed under the terms of the Creative Commons Attribution 4.0 International License (http:// creativecommons.org/licenses/by/4.0/), which permits unrestricted use, distribution, and reproduction in any medium, provided you give appropriate credit to the original author(s) and the source, provide a link to the Creative Commons license, and indicate if changes were made. 
properties of the proteins. To acquire the high-purity and high-activity TGase with food industry standard is still a challenge for bioseparation technology (Luciano and Arntfield 2012).

The applications of commercial TGase products require suitable purification methods. There are various methods for TGase purification, such as ammonium sulfate precipitation, organic solvent precipitation, size-exclusion chromatography, ion-exchange chromatography, and affinity chromatography (Hemung and Yongsawatdigul 2008). Precipitations using ammonium sulfate or organic solvents have low selectivity. Size-exclusion, ion exchange, and affinity chromatography methods are complicated, inefficient, and expensive for large-scale production. This article describes an affinity precipitation method for TGase purification.

Affinity precipitation is a useful technique. The target protein could be precipitated from the crude culture by reversible soluble-insoluble polymer coupled with an affinity ligand (Ding et al. 2014a; Arnold and Chen 2014; Wu et al. 2006). The affinity polymer can be recycled and the affinity ligand on the polymer has high selectivity, so affinity precipitation has already been studied for some bioproducts (Capito et al. 2013; Gagnon et al. 2011; Janoschek et al. 2014; Zhou et al. 2010). A thermoresponsive polymer, 1-vinylimidazole $\mathrm{N}$-isopropylacrylamide, with $\mathrm{Cu}^{2+}$ or $\mathrm{Ni}^{2+}$ as the affinity ligand were synthesized to purify His-tag proteins (Mattiasson et al. 2007). The haptoglobin was used as an affinity ligand connected to a thermoresponsive polymer, poly( $N$-isopropylacrylamide), and the results showed that this method is simpler and has higher purification efficiency than others (Stocker-Majd et al. 2008). A pH-responsive polymer with Cibacron Blue F3GA was applied as the affinity polymer, to purify cellulase. The final purity and activity of the cellulase were 84.4 and $99.8 \%$, respectively (Ding and Cao 2013). The PNVCL-co-MAA-Cu ${ }^{2+}$ was used to precipitate bovine serum albumen (BSA) and the maximum amount of eluted BSA was $37.3 \mathrm{mg} / \mathrm{g}$ polymer (Ling et al. 2012). L-thyroxin has first been used as affinity ligand in our group because of its high selectivity and safety. In this study, L-thyroxin was immobilized to a polymer as the affinity polymer for TGase purification. Affinity process and molecular mechanism have been explored. The study is hopeful to improve present purification process of TGase and to understand molecular mechanism of affinity precipitation.

\section{Methods}

\section{Materials}

$\mathrm{N}$-methylolacrylamide (NMAM), $\mathrm{N}$-isopropylacrylamide (NIPA), azobisisobutyronitrile (AIBN), and butyl acrylate (BA) were purchased from the Sinopharm Chemical Reagent Co., Ltd. (Shanghai, China). L-Thyroxin, pure TGase, L-glutaminehydroxylamine, and $N$-carboxybenzoyl-L-glutaminyl-glycine ( $N$-CBZ-Gln-Gly) were purchased from Sigma (St. Louis, MO, USA). All other chemicals were of analytical reagent grade.

\section{Interactions between L-thyroxin and TGase}

The interactions between L-thyroxin and TGase were investigated using circular dichroism (CD) spectroscopy and FortéBio Octet system (FortéBio Inc., USA) to detect microchanges in protein properties and structures when they were combined with other molecules. 


\section{CD spectroscopy}

Different asymmetric molecules absorb different amounts of circularly polarized light. The CD spectrum shows the relationship between the absorbed amount and wavelength of the light (Brkljaca et al. 2012). CD spectrum was used to compare the changes in the secondary structure of TGase in the presence of different concentrations of L-thyroxin.

\section{FortéBio Octet system}

Biolayer interferometry is a key part of the FortéBio Octet system and the system is used to perform label-free analysis of protein-binding interactions in real time, and is a nonflow dip-and-read system (Li et al. 2011). The analyte is placed in the microplate wells, and ligand-coated sensor tips are immersed in the wells. The system detects the interactions in each well. The affinity polymer were biotinylated by mixing with equivalent amounts of biotin for $30.0 \mathrm{~min}$, then using a PD-10 desalting column (GE Healthcare, USA) to wash out unreacted biotin. The sensors (Super Streptavidin, SSA) were prewetted in dialysis buffer for $15.0 \mathrm{~min}$, held in the biotinylated polymer solution for $15.0 \mathrm{~min}$, and quenched in $10.0 \mu \mathrm{mol} / \mathrm{L}$ biotin for $1.0 \mathrm{~min}$. The unloaded biotinylated polymer was used as controls to calibrate the baseline drift. All these polymers were reacted with L-thyroxin solution, which was prepared in a series of dilutions $(0.5,1.0,1.5,2.0$, and $2.5 \mu \mathrm{mol} / \mathrm{L})$ at room temperature. All tests were performed in triplicate.

\section{Affinity polymer preparation Polymer synthesis}

$\mathrm{P}_{\mathrm{NBN}}$ is a reversible soluble-insoluble polymer that is responsive to temperature changes (Ding and Cao 2013; Shen and Cao 2007). This property comes from the NIPA monomer. NIPA (7.91 g), BA (0.50 mL), and 0.50 g NMAM (0.50 g) were dissolved in ethanol $(100 \mathrm{~mL})$. $\mathrm{O}_{2}$ was removed using $\mathrm{N}_{2}$, and $\operatorname{AIBN}(0.05 \mathrm{~g})$ was added as the initiator. The reaction was performed in a constant-temperature bath at $60{ }^{\circ} \mathrm{C}$ for $24 \mathrm{~h}$. After the reaction completed, the polymer was obtained by vacuum distillation. The precipitate was dissolved in acetone and extracted with $n$-hexane. The white product was obtained after drying in a vacuum.

\section{Affinity ligand immobilization}

Epichlorohydrin $(\mathrm{ECH})$ was introduced to connect the affinity ligand and the polymer (Fig. 1). The polymer, $\mathrm{P}_{\mathrm{NBN}}(1 \%$, w/v), was dissolved in a $1 \mathrm{~mol} / \mathrm{L} \mathrm{NaOH}$ solution and then $0.5 \%(\mathrm{v} / \mathrm{v}) \mathrm{ECH}$ was added. The reaction was performed in a constant-temperature bath at $60{ }^{\circ} \mathrm{C}$ for $24 \mathrm{~h}$. Different amounts of L-thyroxin were reacted with the polymer$\mathrm{ECH}$ at $40{ }^{\circ} \mathrm{C}$ for $2 \mathrm{~h}$, and the $\mathrm{P}_{\mathrm{NBN}}$-thyroxin was precipitated by changing the temperature. The supernatant was collected and the ligand density of the $\mathrm{P}_{\mathrm{NBN}}$-thyroxin was determined using the mass balance calculation.

\section{Measurement of L-thyroxin by HPLC}

A modified method with HPLC system (Shimadzu, Japan) was performed. An analytical reversed-phase column $(Z O R B A X$ C18, $4.6 \times 150 \mathrm{~mm})$ was used at the flow rate $(1.0 \mathrm{~mL} /$ $\mathrm{min})$. All the measurements were performed at room temperature and the samples were detected by UV at $212 \mathrm{~nm}$. The optimal mobile phase used was a mixture of solvent A: $0.1 \%$ phosphoric acid in methanol and solvent B: $0.1 \%$ phosphoric acid in water. 


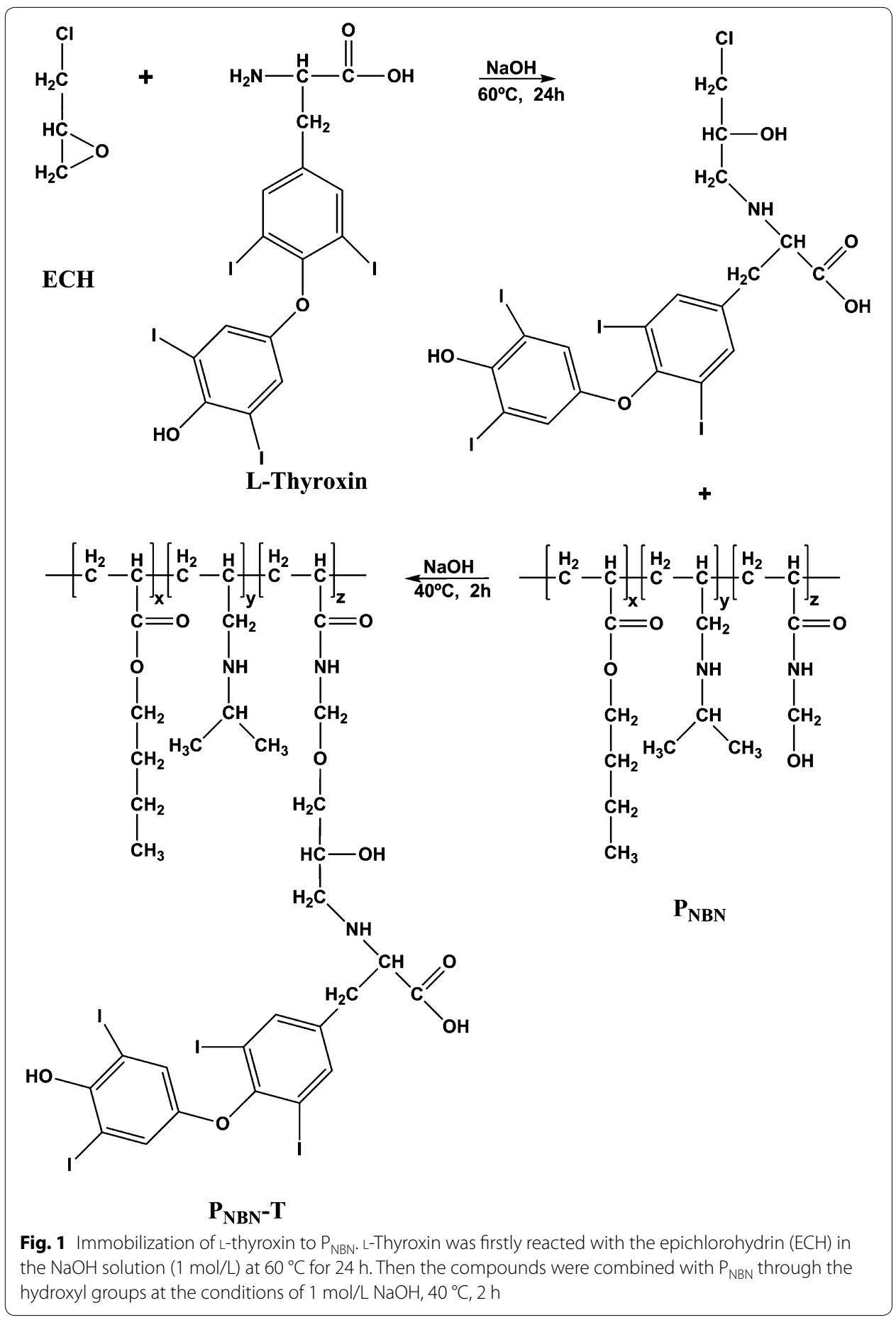

\section{Determination of TGase activity}

The TGase activity was determined based on hydroxamate formation with the substrate, $N$-CBZ-Gln-Gly (Grossowicz et al. 1950). Solution A consisted of hydroxylamine hydrochloride $(0.3475 \mathrm{~g})$, reduced glutathione $(0.1537 \mathrm{~g})$, and N-CBZ-Gln-Gly $(0.5060 \mathrm{~g})$ dissolved in $0.2 \mathrm{~mol} / \mathrm{L}$ Tris- $\mathrm{HCl}$ buffer $(\mathrm{pH} 6.0,50 \mathrm{~mL})$. The final $\mathrm{pH}$ of solution A was 
adjusted to 6.0. Solution B consisted of equal volumes of $5 \% \mathrm{FeCl}_{3} \cdot 6 \mathrm{H}_{2} \mathrm{O}$ solution (dissolved in $0.1 \mathrm{~mol} / \mathrm{L} \mathrm{HCl}), 3 \mathrm{~mol} / \mathrm{L} \mathrm{HCl}$, and $12 \%$ trichloroacetic acid.

A standard curve was obtained as follows. TGase solutions of different concentrations $(0.2 \mathrm{~mL})$ were mixed with solution A $(0.8 \mathrm{~mL})$ and kept in water bath $\left(37^{\circ} \mathrm{C}\right)$ for $10 \mathrm{~min}$. Then solution $\mathrm{B}(1.0 \mathrm{~mL})$ was added to terminate the reaction. After centrifugation for $5 \mathrm{~min}$ at $5000 \mathrm{rpm}$, the absorbance of the supernatant at $525 \mathrm{~nm}$ was measured. The TGase activities of the samples were determined using the method described above.

\section{Adsorption of TGase}

$\mathrm{P}_{\mathrm{NBN}}$-thyroxin was dissolved in water at a $4 \%(\mathrm{w} / \mathrm{v})$ concentration, and $0.4 \mathrm{mg} / \mathrm{mL}$ TGase was prepared with $0.2 \mathrm{~mol} / \mathrm{L}$ phosphate buffer (PB, pH 7.0). Equal volumes of these two solutions were mixed, and the mixture was shaken at $100 \mathrm{rpm}$ for $2 \mathrm{~h}$ at room temperature. A precipitate was obtained by adjusting the temperature of the resultant solution and centrifugation. The supernatant was used for determination of the adsorption ratio from the material balance. During these procedures, parameters such as reaction time, $\mathrm{pH}$, ionic strength, and ligand density which affected the adsorption capacity, were examined. Adsorption isotherms were determined (Pavan et al. 2014).

\section{Elution of TGase}

After precipitation, TGase was eluted from the affinity polymer by breaking the bonding between TGase and L-thyroxin. Different elution agents were used to test elution effect activity of TGase. The precipitated mixture $(1.0 \mathrm{~g})$ was dissolved in the elution agents $(5.0 \mathrm{~mL})$ and shaken at $200 \mathrm{rpm}$ for $2 \mathrm{~h}$. Then $\mathrm{P}_{\mathrm{NBN}}$-thyroxin was precipitated by changing the temperature to above the lower critical solution temperature (LCST), and the supernatant was used for determination of the TGase activity. The $\mathrm{P}_{\mathrm{NBN}}-$ thyroxin was recycled for the next affinity precipitation.

\section{Affinity precipitation of TGase from crude TGase}

Affinity precipitation of TGase from crude TGase was carried out in the same process as above. The optimal adsorption and desorption conditions obtained above were applied in this experiment. The eluted TGase was assayed using SDS-PAGE (Laemmli 1970). $15.0 \%$ acrylamide gels were used in the experiments, and the final gels were stained with $0.25 \%$ Coomassie Brilliant Blue R-250. Crude TGase and pure TGase were used as controls.

\section{Recycle of affinity polymer}

After desorption experiments of the TGase, the affinity polymer was recovered and regenerated with the suitable eluent. The regenerated polymer was reused in the next cycle of purification experiments.

\section{Results and discussion}

\section{CD spectrum}

Figure 2 shows the CD spectra of TGase and L-thyroxin. The CD spectrum of TGase had a negative band in the UV region near $220 \mathrm{~nm}$, which is characteristic of an $\alpha$-helical structure, and the $\alpha$-helix ratio in the secondary structure of TGase decreased from 
$31.98 \%(a)$ to $28.26 \%(b), 25.45 \%(c)$ or $21.08 \%(d)$ as in Fig. 2 by adding different concentrations of L-thyroxin. These results indicate that the ligand underwent interactions with TGase, and that increasing the amount of L-thyroxin caused greater changes in the secondary structure of TGase. This demonstrated that there was a specific affinity interaction between L-thyroxin and TGase.

\section{FortéBio Octet system}

In Fig. 3, the vertical axes represent the adsorbed amount. The results show that adsorption equilibrium time was affected by the initial concentration of L-thyroxin. And with the increase of it, the absorbed amounts grew sharply. According to these tendencies, the dissociation constant $\left(K_{d}\right)$ for this system could be calculated as $18.34 \pm 2.15 \mu \mathrm{mol} / \mathrm{L}$. This showed that L-thyroxin had sufficient TGase affinity strength, and was therefore a suitable ligand for affinity precipitation of TGase.

\section{Affinity precipitation of TGase}

Figure 4a shows that the adsorbed TGase amount increased rapidly at the beginning, while adsorption equilibrium was reached in $60 \mathrm{~min}$ and kept stable. The process was influenced by the concentration of TGase in the solution and the adsorption capacity of $\mathrm{P}_{\mathrm{NBN}}$-thyroxin.

The effect of $\mathrm{pH}$ on adsorption is illustrated in Fig. 4b. The optimal adsorption was achieved at $\mathrm{pH}$ 3.5. The adsorbed TGase amount decreased with $\mathrm{pH}$ increasing. This is because the net charge on the TGase surface approached 0 as the $\mathrm{pH}$ approached the isoelectric point (9.0) of TGase. This reduced binding between L-thyroxin and TGase to result in lower adsorbed TGase amount. To optimize the final TGase activity achieved, the $\mathrm{pH}$ should be controlled at 5.0-8.0. To ensure the TGase stability, pH 5.0 was selected.

The adsorbed amount and activity of TGase were both considered in this assay, because a high ionic strength might affect determination of the TGase activity. As shown in Fig. 4c, high $\mathrm{NaCl}$ concentration decreased the adsorbed amount and activity

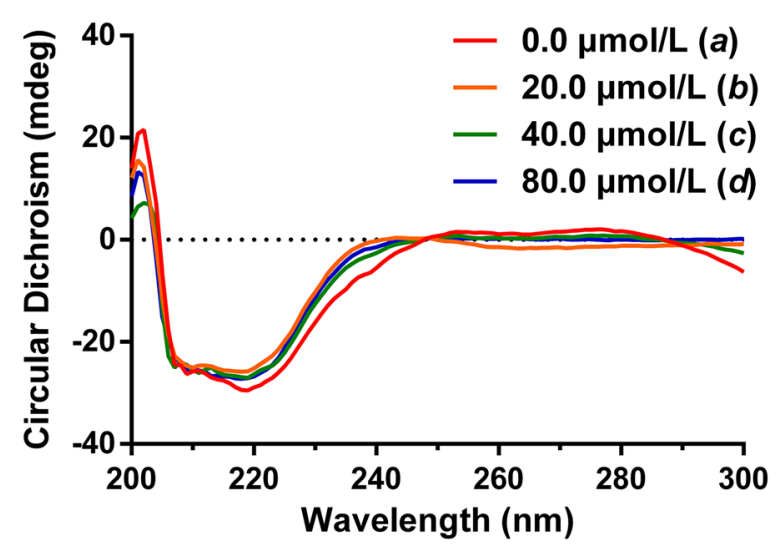

Fig. 2 Interaction CD spectra of TG and L-thyroxin system. Spectra were obtained in $1.0 \mu \mathrm{mol} / \mathrm{L} \mathrm{PB} \mathrm{(pH} \mathrm{7.0,}$ room temperature). TGase concentration was kept at $10.0 \mu \mathrm{mol} / \mathrm{L}$. In the TGase and L-thyroxin systems, the L-thyroxin concentrations were $0.0 \mu \mathrm{mol} / \mathrm{L}(a), 20.0 \mu \mathrm{mol} / \mathrm{L}(b), 40.0 \mu \mathrm{mol} / \mathrm{L}(c)$, and $80.0 \mu \mathrm{mol} / \mathrm{L}$ (d) 


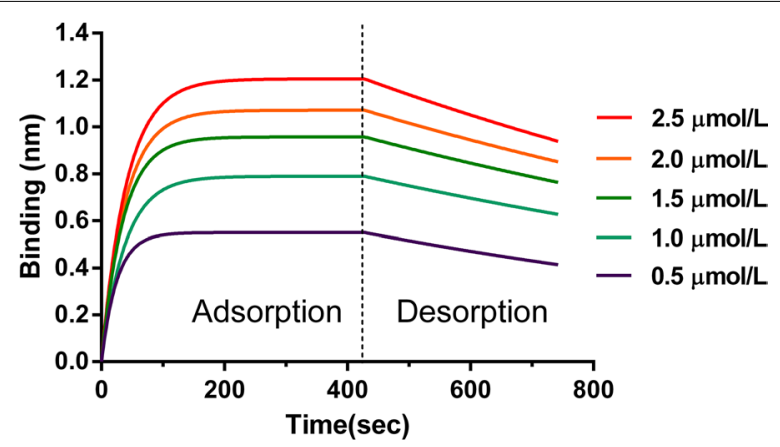

Fig. 3 The results of FortéBio Octet assay. Vertical and horizontal axes represent light shift distance (nm) for different concentrations of TGase in solution and adsorption/desorption time (s)

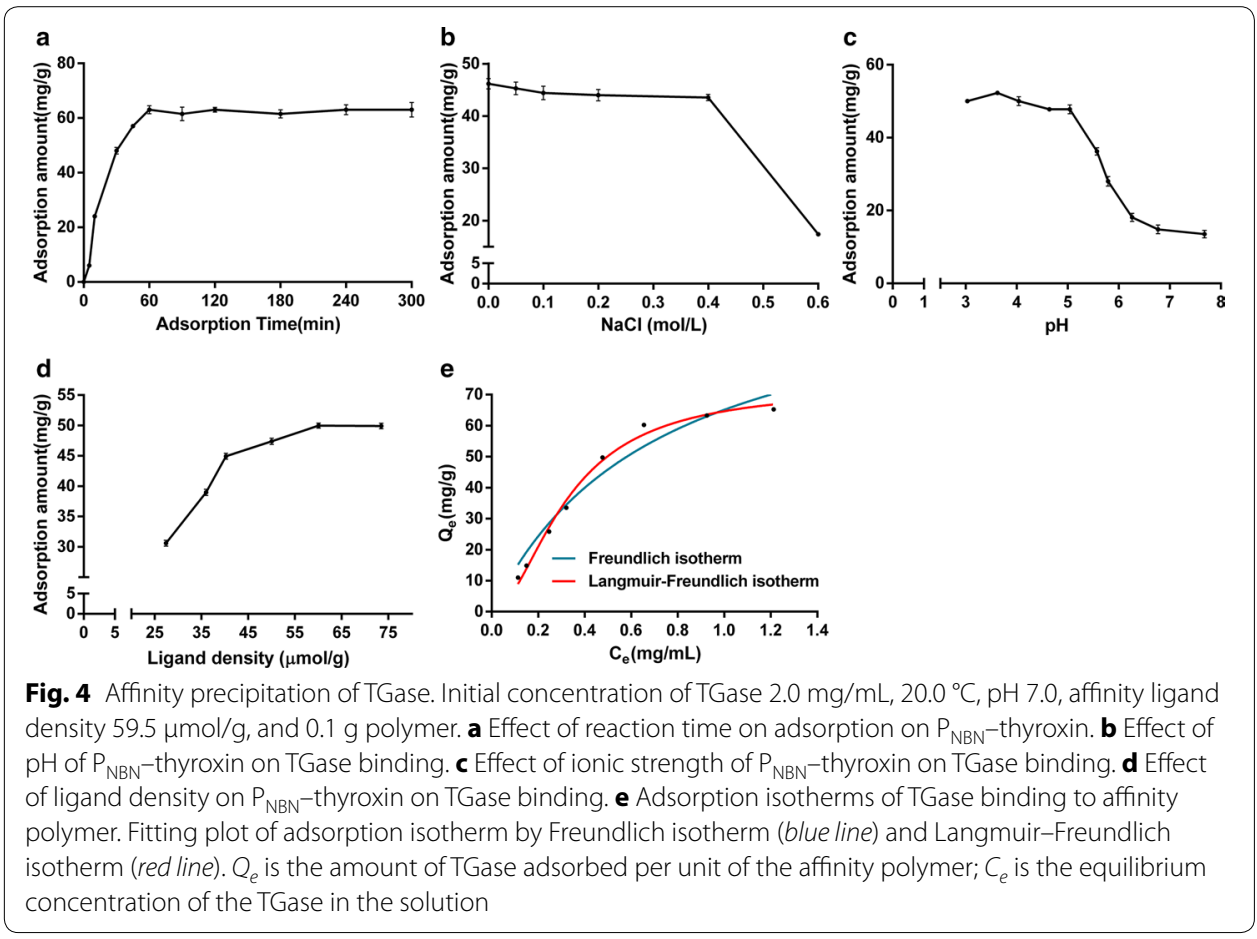

simultaneously. High ionic strength would destroy the hydrophilicity of the $\mathrm{P}_{\mathrm{NBN}}$-thyroxin, resulting in polymer precipitation, and weakening the binding between ligand and TGase to reduce adsorbed amount. A high ionic strength could also cause changes of the enzyme conformation. As a result, $0 \mathrm{mg} / \mathrm{mL} \mathrm{NaCl}$ was chosen as the final selection.

Figure $4 \mathrm{~d}$ shows the effect of ligand density on $\mathrm{P}_{\mathrm{NBN}}$-thyroxin on the adsorbed TGase amount. When the ligand density was below $50.0 \mu \mathrm{mol} / \mathrm{g}$, the adsorbed TGase amount increased with increasing of ligand density. While ligand density was above $50.0 \mu \mathrm{mol} / \mathrm{g}$, adsorption amount approached to stable. At a low ligand density, the amount of TGase bound to the polymer would increase with ligand density. However, at a high ligand density, more ligands on the polymer would increase steric hindrance, decreasing the possibility of TGase attaching to the ligand. Ligand density at $59.5 \mu \mathrm{mol} / \mathrm{g}$ was chosen for affinity precipitation of TGase. 
In consideration of the characters of the affinity polymer and target protein, the Freundlich isotherm and Langmuir-Freundlich (LF) isotherm equations which were used to describe heterogeneous adsorption systems were selected to correlate the experimental data of adsorption isotherm of affinity precipitation (Dhawan et al. 2015).

The Freundlich isotherm relates the adsorbed concentration as the power function of free solute concentration. One limitation of the Freundlich model is that the amount of adsorbed solute increases indefinitely with the free solute concentration. This empirical equation takes the form (Arıca and Bayramoğlu 2005; Arıca et al. 2004).

$$
Q_{e}=K_{F} C_{e}^{b_{F}}
$$

where $b_{F}$ is the Freundlich constant, $K_{F}$ is the adsorption coefficient, $Q_{e}(\mathrm{mg} / \mathrm{g})$ is the amount of TGase adsorbed per unit of the affinity polymer, and $C_{e}(\mathrm{mg} / \mathrm{mL})$ is the free concentration of the TGase in the solution. This expression is characterized by the Freundlich constant, $b_{F}$, and so the Freundlich isotherm may be used to describe heterogeneous systems.

For LF isotherm, it is also used to describe the adsorption from dilute solutions on heterogeneous surfaces. It has an advantage that it can estimate the value of maximum adsorption capacity. It can be expressed as followed (Umpleby et al. 2001; Umpleby II et al. 2001):

$$
Q_{e}=Q_{m} a C_{e}^{m} /\left(1+a C_{e}^{m}\right)
$$

where $Q_{m}(\mathrm{mg} / \mathrm{g})$ is the maximum adsorption capacity, $a$ is related to association constant $\left(K_{0}\right)$ via $K_{0}=a^{1 / m}, m$ is heterogeneity parameter, $Q_{e}$ and $C_{e}$ is the same as above equation.

Figure $4 \mathrm{e}$ shows the fitting plot of $Q_{e}$ versus $C_{e}$ using two models above, and Table 1 presents the fitting parameters. As shown in the Table 1 , the value of $R^{2}$ of LF isotherm was 0.9970 , which is better than the $\mathrm{R}^{2}(0.9820)$ of Freundlich isotherm, which meant LF equation had better consistency with the experimental data.

As for Freundlich constant in Table 1, $b_{F}(0.7153)$ was less than 1, because the surface of affinity polymer was heterogeneous, and the TGase concentration on the polymer would increase as long as there was an increase in the initial TGase concentration. Meanwhile, for LF isotherm, $Q_{m}$ was $123.2 \mathrm{mg} / \mathrm{g}$ and $K_{0}$ was 1.336 . The fact that $m$ value was not equal to 1 implied that the binding sites of affinity polymer were heterogeneous which identified with Freundlich isotherm. According to $K_{0}$, the dissociation constant $\left(K_{d}\right)$ was $0.7483 \mathrm{mg} / \mathrm{mL}$, via $K_{d}=1 / K_{0}$. As the molecular weight of TGase is 38,000 Da, the value of $Q_{m}$ and $K_{d}$ could be converted to $3.242 \mu \mathrm{mol} / \mathrm{g}$ and $19.69 \mu \mathrm{mol} / \mathrm{L}$. In comparison with the results of Octet system, the value was closed to each other within the accepted error range. LF isotherm equation was much more suitable for the simulation of this affinity precipitation isotherm.

\begin{tabular}{|c|c|c|c|c|c|c|}
\hline \multicolumn{3}{|c|}{ Freundlich isotherm } & \multicolumn{4}{|c|}{ Langmuir-Freundlich isotherm } \\
\hline$K_{F}(\mathrm{mg} / \mathrm{mL})$ & $b_{F}$ & $\mathrm{R}^{2}$ & $Q_{m}(\mathrm{mg} / \mathrm{g})$ & $a(\mathrm{mg} / \mathrm{mL})$ & $m$ & $\mathrm{R}^{2}$ \\
\hline 71.89 & 0.7153 & 0.9820 & 123.2 & 1.419 & 1.207 & 0.9970 \\
\hline
\end{tabular}

Table 1 Fitting parameters of Freundlich isotherm and Langmuir-Freundlich isotherm 


\section{Elution}

Ten elution conditions were used to determine the optimal elution condition, based on the properties of L-thyroxin and TGase. The data in Table 2 show that pH 10.0 Gly$\mathrm{NaOH}$ buffer obtained $99.01 \%$ protein recovery and $98.05 \%$ activity recovery, respectively. $0.02 \mathrm{~mol} / \mathrm{L}$ phosphate buffer $(\mathrm{pH} 7.0$ ) with $0.5 \mathrm{~mol} / \mathrm{L}$ urea obtained $99.12 \%$ protein recovery, while TGase activity recovery was only $80.89 \%$. None of other groups gave sufficient high TGase activity recovery, so Gly- $\mathrm{NaOH}(\mathrm{pH} 10.0)$ was chosen as the elution agent.

The traditional separation methods were usually applied for microbial TGase, such as ammonium sulfate precipitation, organic solvent precipitation, size-exclusion chromatography, ion-exchange chromatography and so on. A number of components existed in the fermentation broth resulted in the complicated process for separation of TGase. The group of Shi acquired the purified TGase through alcohol precipitation, ammonium sulphate precipitation, and ultrafiltration gel chromatography. The final purification factor was 10.42 and activity recovery was $27.3 \%$ (Shi et al. 2011). A simple purification process was applied by Macedo et al. The process includes two successive chromatography processes with Sephadex G-75 columns, with 48 and $17 \%$ recovery, respectively (Macedo et al. 2011).

\section{SDS-page}

Crude TGase, pure TGase, and TGase purified by affinity precipitation were all analyzed using SDS-PAGE; and the results are shown in Fig. 5. Lanes 1 and 4 represent crude TGase and pure TGase, respectively. TGase eluted by Gly- $\mathrm{NaOH}(\mathrm{pH} 10.0)$ is in lane 2 , and lane 3 represents TGase eluted by PB ( $\mathrm{pH} 7.0$ ) containing $0.5 \mathrm{~mol} / \mathrm{L}$ urea. For all four lanes, the TGase molecular weight was about $38 \mathrm{kD}$. The lane 2 of TGase purified by affinity precipitation show single band, while it seems that lane 3 show impurity bands. The results of lane 3 was caused by strong desorption and denaturation of urea for proteins which had other bands of different molecular weight. Pure TGase was obtained using affinity precipitation when Gly- $\mathrm{NaOH}$ ( $\mathrm{pH} 10.0)$ was used as elution agent.

Rickert and the group used a two-step affinity purification method to achieve TGase of electrophoretic purity (Rickert et al. 2015). Compared with these methods mentioned above all, affinity precipitation is simpler and obtain higher yield and purity. In

Table 2 Different elution agents and results

\begin{tabular}{llll}
\hline Group & Elution condition & Elution recovery of protein (\%) & Elution recovery of activity (\%) \\
\hline 1 & $0.5 \mathrm{~mol} / \mathrm{L} \mathrm{NaSCN}$ & 56.30 & 54.01 \\
2 & $1.0 \mathrm{~mol} / \mathrm{L} \mathrm{NaSCN}$ & 84.01 & 85.10 \\
3 & $0.1 \mathrm{~mol} / \mathrm{L} \mathrm{EDTA}$ & 91.09 & 90.02 \\
4 & $1 \mathrm{~mol} / \mathrm{L} \mathrm{KSCN}$ & 85.79 & 79.34 \\
5 & $\mathrm{pH} 7.0 \mathrm{~PB}+$ 0.5 mol/L Urea & 99.12 & 80.89 \\
6 & $\mathrm{pH} 7.0 \mathrm{~PB}+1.0 \%$ Triton 100 & 17.85 & 10.98 \\
7 & $\mathrm{pH} 7.0 \mathrm{~PB}+20.0 \%$ Glycol & 89.96 & 85.09 \\
8 & $\mathrm{pH} 8.0 \mathrm{Gly}-\mathrm{NaOH}$ & 36.22 & 40.87 \\
9 & $\mathrm{pH} 9.0 \mathrm{Gly}-\mathrm{NaOH}$ & 56.50 & 61.40 \\
10 & $\mathrm{pH} 10.0 \mathrm{Gly}-\mathrm{NaOH}$ & 99.01 & 95.85 \\
\hline
\end{tabular}




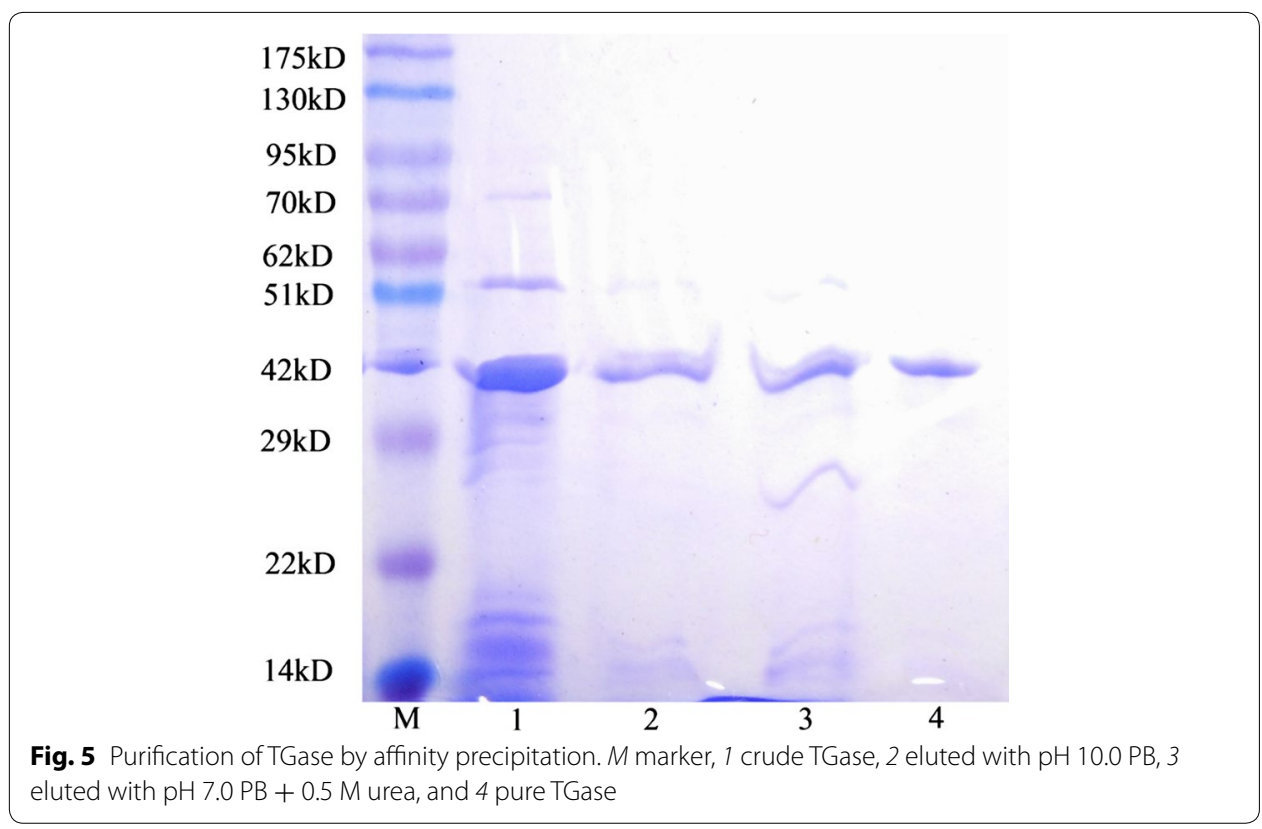

consideration of large-scale production for TGase, affinity precipitation is also a better choice.

\section{Recycle of $\mathrm{P}_{\mathrm{NBN}}$-thyroxin}

$\mathrm{P}_{\mathrm{NBN}}$ was synthesized as described in the method. The LCST is $31.0^{\circ} \mathrm{C}$, and its recovery still reached $96.0 \%$ at the five cycles with relation to initial amount, respectively. This shows that $\mathrm{P}_{\mathrm{NBN}}$ was stable after repeated dissolution and precipitation. After L-thyroxin was attached to the polymer, the LCST is $31.6{ }^{\circ} \mathrm{C}$, with $0.6{ }^{\circ} \mathrm{C}$ rising. Recovery of $\mathrm{P}_{\mathrm{NBN}^{-}}$ thyroxin was $99.6 \%$ at the five cycles with relation to initial amount. Theoretically, the affinity polymer could be recycled more than 60 times if recovery is over $95 \%$ every recycle. This new affinity polymer can reduce the cost in a large extent, and show great potential application in industry.

Various kinds of proteins have different character for environmental stimulus. Aiming at the applicability of affinity precipitation, we have prepared diverse affinity precipitation systems with smart polymers ( $\mathrm{pH}$-responsive or thermos-responsive) to purify different proteins. Specific affinity ligands were also selected based on the interaction between the target proteins and ligands (Ding et al. 2014b; Zhou et al. 2010; Shen and Cao 2007).

\section{Conclusion}

In this study, a thermo-responsive polymer $\mathrm{P}_{\mathrm{NBN}}$ was synthesized and then ligand L-thyroxin was coupled to the polymer. The LCST of the affinity polymer closed to room temperature was useful for reducing energy consumption and retaining high activity of the enzyme. Furthermore, the high recycling ratio of the affinity polymer could ensure its reusability. Optimal adsorptions were achieved at a suitable adsorption condition of $\mathrm{pH}=5.0$ and $0 \mathrm{mg} / \mathrm{mL} \mathrm{NaCl}$. And Gly- $\mathrm{NaOH}$ ( $\mathrm{pH} 10.0)$ was used as the best elution 
condition in which $99.01 \%$ protein recovery and $98.05 \%$ activity recovery was obtained, respectively. The SDS-PAGE showed the molecular weight of main band was corresponding to that of the native TGase $(38 \mathrm{kD})$. The results reported here indicated that TGase could be efficiently purified using affinity precipitation.

\section{Authors' contributions}

SPL, ZYD and XJC constructed the idea and methods for this work. ZYD developed the system of affinity carrier and SPL optimized the conditions for affinity precipitation of TGase. The determination of CD spectrum and Octet were completed by SPL. All authors read and approved the final manuscript.

\section{Acknowledgements}

This work was supported by the National Special Fund for State Key Laboratory of Bioreactor Engineering (No. 2060204) in East China University of Science and Technology. The technical support from instrument platform in State Key Laboratory of Bioreactor Engineering also was highly appreciated.

\section{Competing interests}

The authors declare that they have no competing interests.

Received: 7 November 2015 Accepted: 6 January 2016

Published online: 15 January 2016

\section{References}

Arıca MY, Bayramoğlu G (2005) Purification of lysozyme from egg white by Reactive Blue 4 and Reactive Red 120 dye-ligands immobilised composite membranes. Process Biochem 40(3-4):1433-1442. doi:10.1016/j. procbio.2004.06.028

Arıca MY, Yılmaz M, Yalçın E, Bayramoğlu G (2004) Affinity membrane chromatography: relationship of dye-ligand type to surface polarity and their effect on lysozyme separation and purification. J Chromatogr B 805(2):315-323. doi:10.1016/j.jchromb.2004.03.021

Arnold L, Chen R (2014) Novel thermo-responsive fucose binding ligands for glycoprotein purification by affinity precipitation. Biotechnol Bioeng 111(2):413-417. doi:10.1002/Bit.25118

Binsi PK, Shamasundar BA (2012) Purification and characterisation of transglutaminase from four fish species: effect of added transglutaminase on the viscoelastic behaviour of fish mince. Food Chem 132(4):1922-1929. doi:10.1016/j. foodchem.2011.12.027

Brkljaca Z, Condic-Jurkic K, Smith AS, Smith DM (2012) Calculation of the CD spectrum of a peptide from its conformational phase space: the case of Met-enkephalin and its unnatural analogue. J Chem Theory Comput 8(5):1694-1705 doi:10.1021/ct200868y

Capito F, Bauer J, Rapp A, Schroter C, Kolmar H, Stanislawski B (2013) Feasibility study of semi-selective protein precipitation with salt-tolerant copolymers for industrial purification of therapeutic antibodies. Biotechnol Bioeng 110(11):2915-2927. doi:10.1002/bit.24950

Chica RA, Gagnon P, Keillor JW, Pelletier JN (2004) Tissue transglutaminase acylation: proposed role of conserved active site Tyr and Trp residues revealed by molecular modeling of peptide substrate binding. Protein Sci 13(4):979-991. doi:10.1110/ps.03433304

Dhawan R, Bhasin KK, Goyal M (2015) Isotherms, kinetics and thermodynamics for adsorption of pyridine vapors on modified activated carbons. Adsorption 21(1-2):37-52. doi:10.1007/s10450-015-9648-x

Ding Z, Cao X (2013) Affinity precipitation of human serum albumin using a thermo-response polymer with an L-thyroxin ligand. BMC Biotechnol 13(1):109. doi:10.1186/1472-6750-13-109

Ding Z, Kang L, Cao X (2014a) Application of docking methods for metal chelate affinity precipitation of endo-glucanase using pH-response polymer. Colloids Surf B 113:412-420. doi:10.1016/j.colsurfb.2013.09.041

Ding Z, Li S, Cao X (2014b) Separation of lysozyme from salted duck egg white by affinity precipitation using pH-responsive polymer with an L-thyroxin ligand. Sep Purif Technol 138:153-160. doi:10.1016/j.seppur.2014.10.021

Folk J (1980) Transglutaminases. Annu Rev Biochem 49(1):517-531

Gagnon M, Hiller G, Luan YT, Kittredge A, DeFelice J, Drapeau D (2011) High-end pH-controlled delivery of glucose effectively suppresses lactate accumulation in CHO fed-batch cultures. Biotechnol Bioeng 108(6):1328-1337. doi:10.1002/bit.23072

Grossowicz N, Wainfan E, Borek E, Waelsch H (1950) The enzymatic formation of hydroxamic acids from glutamine and asparagine. J Biol Chem 187(1):111-125

Hemung BO, Yongsawatdigul J (2008) Partial purification and characterization of transglutaminase from threadfin bream (Nemipterus sp.) liver. J Food Biochem 32(2):182-200. doi:10.1111/j.1745-4514.2008.00154.x

Janoschek L, Freiherr von Roman M, Berensmeier S (2014) Protein A affinity precipitation of human immunoglobulin G. J Chromatogr B Anal Technol Biomed Life Sci 965:72-78. doi:10.1016/j.jchromb.2014.06.011

Laemmli UK (1970) Cleavage of structural proteins during the assembly of the head of bacteriophage T4. Nature 227(5259):680-685

Li J, Schantz A, Schwegler M, Shankar G (2011) Detection of low-affinity anti-drug antibodies and improved drug tolerance in immunogenicity testing by Octet((R)) biolayer interferometry. J Pharm Biomed Anal 54(2):286-294. doi:10.1016/j.jpba.2010.08.022 
Ling YQ, Nie HL, Brandford-White C, Williams GR, Zhu LM (2012) Metal chelate affinity precipitation: purification of BSA using poly(N-vinylcaprolactam-co-methacrylic acid) copolymers. Colloids Surf B 94:281-287. doi:10.1016/j. colsurfb.2012.02.004

Luciano BF, Arntfield S (2012) Use of transglutaminases in foods and potential utilization of plants as a transglutaminase source-review. Biotemas 25(4):1-11. doi:10.5007/2175-7925.2012v25n4p1

Macedo JA, Sette LD, Sato HH (2011) Purification and characterization of a new transglutaminase from Streptomyces Sp. isolated in Brazilian Soil. J Food Biochem 35(4):1361-1372. doi:10.1111/j.1745-4514.2010.00456.x

Mattiasson B, Kumar A, Ivanov AE, Galaev IY (2007) Metal-chelate affinity precipitation of proteins using responsive polymers. Nat Protoc 2(1):213-220

Pardin C, Roy I, Chica RA, Bonneil E, Thibault P, Lubell WD, Pelletier JN, Keillor JW (2009) Photolabeling of tissue transglutaminase reveals the binding mode of potent cinnamoyl inhibitors. Biochemistry 48(15):3346-3353. doi:10.1021/ bi802021c

Pavan GL, Bresolin ITL, Borsoi-Ribeiro M, Vijayalakshmi M, Bueno SMA (2014) The effect of NaCl on the adsorption of human IgG onto CM-Asp-PEVA hollow fiber membrane-immobilized nickel and cobalt metal ions. Adsorption 20(5-6):677-688. doi:10.1007/s10450-014-9612-1

Rickert M, Strop P, Lui V, Melton-Witt J, Esteban Farias S, Foletti D, Shelton D, Pons J, Rajpal A (2015) Production of soluble and active microbial transglutaminase in Escherichia coli for site-specific antibody drug conjugation. Protein Sci. doi:10.1002/pro.2833

Shen L, Cao X (2007) Synthesis of thermo-sensitive polyacrylamide derivatives for affinity precipitation and its application in purification of lysozyme. Biochem Eng J 33(1):66-71. doi:10.1016/j.bej.2006.10.006

Shi Y, Qian L, Zhang N, Han C, Liu Y, Zhang Y, Ma Y (2011) Study on separation and purification of the transglutaminase. Appl Mech Mater 121-126:443-447. doi:10.4028/www.scientific.net/AMM.121-126.443

Stocker-Majd G, Hilbrig F, Freitag R (2008) Extraction of haemoglobin from human blood by affinity precipitation using a haptoglobin-based stimuli-responsive affinity macroligand. J Chromatogr A 1194(1):57-65. doi:10.1016/j. chroma.2008.03.091

Umpleby RJ, Baxter SC, Chen Y, Shah RN, Shimizu KD (2001) Characterization of molecularly imprinted polymers with the Langmuir-Freundlich isotherm. Anal Chem 73(19):4584-4591

Wilhelm B, Meinhardt A, Seitz J (1996) Transglutaminases: purification and activity assays. J Chromatogr B Biomed Appl 684(1-2):163-177

Worratao A, Yongsawatdigul J (2005) Purification and characterization of transglutaminase from Tropical tilapia (Oreochromis niloticus). Food Chem 93(4):651-658. doi:10.1016/j.foodchem.2004.09.044

Wu F, Zhu Y, Jia Z (2006) Preparation of dye-ligand affinity chromatographic packings based on monodisperse poly(glycidylmethacrylate-co-ethylenedimethacrylate) beads and their chromatographic properties. J Chromatogr A 1134(1-2):45-50. doi:10.1016/j.chroma.2006.07.087

Zhao X, Shaw AC, Wang J, Chang CC, Deng J, Su J (2010) A novel high-throughput screening method for microbial transglutaminases with high specificity toward Gln141 of human growth hormone. J Biomol Screen 15(2):206-212 doi:10.1177/1087057109356206

Zhou L, Wan J, Cao X (2010) Synthesis of thermo-sensitive copolymer with affinity butyl ligand and its application in lipase purification. J Chromatogr B Anal Technol Biomed Life Sci 878(15-16):1025-1030. doi:10.1016/j. jchromb.2010.03.001

\section{Submit your manuscript to a SpringerOpen ${ }^{\circ}$ journal and benefit from:}

- Convenient online submission

- Rigorous peer review

- Immediate publication on acceptance

- Open access: articles freely available online

- High visibility within the field

- Retaining the copyright to your article

Submit your next manuscript at $\boldsymbol{s p r i n g e r o p e n . c o m ~}$ 